\title{
VALLEY-FILL SANDSTONES IN THE KOOTENAI FORMATION ON THE CROW INDIAN RESERVATION\# SOUTH-CENTRAL MONTANA
}

Quarterly Technical Report

Report Period : 01/01/1997 - 03/31/1997

Author: David A. Lopez

Report Issue Date: 04/01/1997

DE-FG22-96BC14996

Montana Bureau of Mines and Geology

MSU-Billings, Campus Box 112

1500 N 30th Street

Billings, MT 59101 


\section{Disclaimer}

This report was prepared as an account of work sponsored by an agency of the United States Government. Neither the United States Government nor any agency thereof, nor any of their employees, makes any warranty, express or implied, or assumes any legal liability or responsibility for the accuracy, completeness, or usefulness of any information, apparatus, product, or process disclosed, or represents that its use would not infringe privately owned rights. Reference herein to any specific commercial product, process, or service by trade name, trademark, manufacturer, or otherwise, does not necessarily constitute or imply its endorsement, recommendation, or favoring by the United States Government or any agency thereof. The views and opinions of authors expressed herein do not necessarily state or reflect those of the United States Government or any agency thereof. 


\begin{abstract}
Field investigation of the Kootenai valley-fill sandstones was begun in the first quarter. About one half of the outcrop belt was inventoried for occurrences of channel sandstone before heavy snows came to the area. Five exposures of valley-fill sandstone have been located, of these two are 15 meters (50 feet) or greater in thickness and have excellent porosity and permeability. These will be measured and studied in detail during the next field season (1997). No further field work was possible during the second and third quarters because of snow cover.

Subsurface data is being collected, organized, and a digital database is being prepared for the project. Geographix petroleum software will probably be used to manage and manipulate the data. Regional subsurface cross sections are being constructed for correlation purposes.

All of the four 30' X 60' geologic quadrangles, the Billings, Bridger, Hardin, and Lodge Grass, have been scanned to produce a digital surface geologic data base for the Crow Reservation. These maps are currently being proofed and edited for accuracy.

A four-day oil and gas training seminar for Crow Tribal members was completed and was quite successful. The purpose was to enable tribal members and employees to understand and evaluate potential exploration prospects and offers that may result from the completion of this research project.
\end{abstract}




\section{Table of Contents}

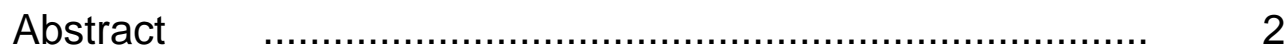

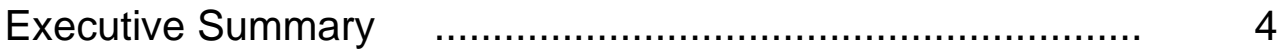

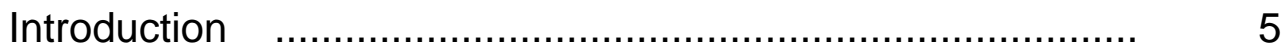

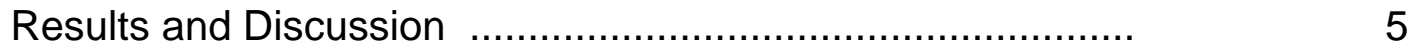

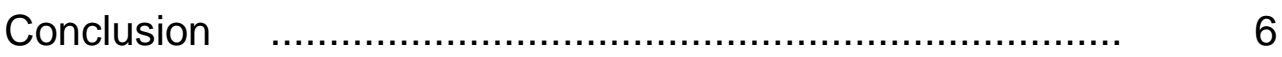




\section{Executive Summary}

Field investigation of the Kootenai valley-fill sandstones was begun in the first quarter; no field work has been possible during the second and third quarters because of snow cover.

Subsurface data is being collected, organized, and a digital database is being prepared for the project. Geographix petroleum software will probably be used to manage and manipulate the data.

All of the four 30' $X 60^{\prime}$ ' geologic quadrangles have been scanned to produce a digital surface geologic data base for the Crow Reservation. Processing and editing of this data continues in order to produce a high-quality surface geologic data base for the reservation. The Billings 30'X60' Quadrangle is nearing completion; the Bridger, Lodge Grass, and Hardin Quadrangles have all undergone at least one proofing stage.

A training seminar for Crow Tribal members was completed this quarter. Fifteen Crow Tribal Administration employees, Bureau of Indian Affairs employees, and tribal members attended the seminar. 


\section{Introduction}

The stratigraphic study of the valley-fill sandstones in the Kootenai Formation was begun in August, 1996 with reconnaissance field work to locate the exposures of channel sandstone deposits. Subsurface aspects of the project were begun in the second quarter and are continuing.

Digitization of surface geologic maps of the Crow Reservation area continues, as well as processing and editing of the data. An oil and gas training seminar for Crow Tribal members was completed this quarter.

\section{Results and Discussion}

Subsurface data collection was begun in the second quarter of this project, and continues this quarter. A collection of most of the oil and gas well logs for the Crow Reservation area was donated to the project by a company that had initiated an exploration program on the reservation several years ago. These have been filed and inventoried to determine missing well coverage. Regional subsurface cross sections have begun to be constructed for correlation purposes and to identify facies changes that may be of importance to the project.

A digital data base of commercially available "scout card" data has been generated using Microsoft Access. Currently, the data base and software options are being evaluated, in order to decide how best to digitally manage the database that will be generated by the project. Geographix software, a comprehensive system for the storage and manipulation of petroleum information, including base map generation, is available at Montana Tech (the Montana Bureau of Mines and Geology is a department of Montana Tech). The feasibility of using this system has been evaluated, and cost of acquisition of the software for the Billings office is being researched.

The Geologic Map of the Billings 30' X 60' quadrangle was digitally scanned during the first quarter of this study for the geologic data base that will be provided to the Crow Tribe. This is the northwest quarter of the total area that will have to be produced in digital form under this contract. Proofing and editing of the the Billings map is nearly complete. The Bridger, Hardin, and Lodge Grass 30' X 60' quadrangles have all been scanned and are in various stages of processing and editing. The Lodge Grass quadrangle will require a limited amount of field checking during the next field season.

A four-day oil and gas training seminar for the Crow Tribe was completed this quarter. The purpose was to enable tribal members and employees to understand and evaluate potential exploration prospects and offers that may result from the completion of this research project. The seminar was conducted over four consecutive Wednesdays in January and February. Fifteen Crow Tribal members, and employees of the Crow Tribal Administration and the Bureau of Indian Affairs completed the seminar. Various other tribal members 
attended individual sessions but did not complete all four sessions, mainly because of scheduling conflicts. The topics covered were as follows:

Day 1: Basic geologic principles necessary for understanding the remainder of the seminar.

Day 2: Basics of petroleum geology; source rocks, generation of hydrocarbons, migration, timing, traps, reservoirs, and seals. This session included a half day field trip to examine a structural trap at a nearby oil field and to examine reservoir rocks exposed along the northeastern flank of the Big Horn Mountains.

Day 3: Subsurface data, geophysical logs, cross-sections, subsurface maps, mapping techniques, and contouring were covered. A hands-on project involving subsurface structural and reservoir mapping was included. Students discussed potential prospects and drilling sites based on their maps.

Day 4: The business side of oil and gas exploration and development. Topics discussed included: leasing and lease forms, calculation of reserves, calculation of chance of success, and present value of a prospect. This session included a half day field trip to a producing oil field to discuss economics, engineering, and environmental aspects.

At the end of the seminar, students were asked to fill out an evaluation questionnaire and to make comments concerning the course and the material covered. Feedback was very positive, except a few students would have liked more basic geology. Students were presented with a certificate of achievement after they completed the seminar.

\section{Conclusion}

Subsurface data is being collected, organized, and a digital database is being prepared for the project. Geographix petroleum software will probably be used to manage and manipulate the data.

All four 30' X 60' geologic quadrangles have been scanned to produce a digital surface geologic data base for the Crow Reservation. The Billings Quadrangle is nearing completion. Processing and editing of these data are ongoing.

A four-day oil and gas training seminar for Crow Tribal members was completed and was quite successful. The purpose was to enable tribal members and employees to understand and evaluate potential exploration prospects and offers that may result from the completion of this research project. 